\title{
Sovereign Credit Ratings in „New“ EU Member States - A Comparative Analysis in Times of Crisis and Tranquility ${ }^{1}$
}

\author{
Ewa STAWASZ-GRABOWSKA* - Joanna STAWSKA**
}

\begin{abstract}
This paper investigates the impact of quantitative and qualitative factors on the long-term sovereign credit ratings of nine countries that joined the European Union in 2004 (Czechia, Estonia, Hungary, Latvia, Lithuania, Malta, Poland, Slovakia, and Slovenia). Among this group, two subgroups are distinguishedeuro area members and countries that pursue an independent monetary policy. The analysis is conducted for the period of 2004q1-2018q4, which is later divided into pre-crisis, crisis, and post-crisis sub-periods. Using a panel fixed effects model with robust standard errors, we find that the macroeconomic variables played the dominant role throughout the period under analysis, and particularly during the crisis. Moreover, the quality of governance had an important impact on the ratings in all three sub-periods. We also find that euro area membership has provided additional benefits in terms of countries' perceived credibility.
\end{abstract}

Keywords: sovereign credit ratings, „new“ EU member states, euro area crisis

JEL Classification: G24, E52, E62

DOI: https://doi.org/10.31577/ekoncas.2021.06.01

\section{Introduction}

Sovereign credit ratings are used as measures of countries' (perceived) credibility and willingness to repay their debt obligations in full and on time. They reflect countries' economic, financial and political situation as well as their level

* Ewa STAWASZ-GRABOWSKA, corresponding author, University of Lodz, Faculty of Economics and Sociology, Department of International Finance and Investments, 3/5 POW Street, 90-255 Lodz, Poland; e-mail: ewa.grabowska@uni.lodz.pl

** Joanna STAWSKA, University of Lodz, Faculty of Economics and Sociology, Department of Central Banking and Financial Intermediation, 39 Rewolucji Street, 90-214 Lodz, Poland; e-mail: joanna.stawska@uni.lodz.pl

${ }^{1}$ This work was supported by the National Science Centre Poland, grant No. UMO-2017/26/D/ HS4/00954. The authors report no conflicts of interest. 
of economic development. Countries care about the best possible assessments due to the following considerations. First, a credit rating determines the country's terms of access to the international capital market. Second, the sovereign credit rating constitutes the benchmark for ratings given to various domestic entities such as banks or companies. This phenomenon is known as the sovereign ceiling doctrine (Luitel, Vanpée and De Moor, 2016). Third, some investors are constrained by law as to the asset quality they can hold in their portfolios. This quality is reflected by credit ratings.

Credit ratings are ascribed by credit rating agencies (CRAs), out of which three American agencies, i.e., Standard \& Poor's (S\&P), Moody's, and Fitch Ratings, are the most influential. In their decision-making process, CRAs take into consideration two main groups of factors. The first one encompasses factors reflecting issuers' economic and financial standing. The second one pertains to qualitative characteristics such as the political system and its stability, degree of corruption, governance, etc.

Determinants of sovereign credit ratings have been studied in a number of papers despite regularly published reports in which CRAs identify factors taken into consideration. This is due to the fact that the weights ascribed to those factors are not revealed (Dopierała, Ilczuk and Wojciechowski, 2020). Moreover, the final decisions on credit ratings might differ from what is implied by qualitative and quantitative analyses as they are subject to judgmental adjustments of credit rating committees (De Moor et al., 2018).

Although many studies have examined the determinants of sovereign credit ratings, relatively little attention has been given to the so-called „new“ European Union (EU) member states. In 2004, a group of ten countries joined the ranks of the EU, seven of which accepted the euro, while three conduct their monetary policy independently. Admittedly, they have been included in previous analyses, but usually as part of a broader category of emerging markets or lower-rated countries. In retrospect, it is worth exploring how these two groups stacked up in terms of perceived default risk. Furthermore, in the years $2004-2018$, the EU, and the euro area in particular, experienced fast-changing economic conditions, including periods of (relative) tranquility and a period of severe crisis, which threatened the functioning of the currency union and the common market. Hence, the aim of this paper is to identify the factors that shape the sovereign credit ratings of the „new“ EU members in the period of 2004 - 2018, with a special focus on the status of a (non)euro area member and against the background of the changing economic situation.

The contribution of this paper to the existing literature is threefold. First, we explore the determinants of the sovereign credit ratings of the EU countries from 
Central and Eastern Europe (CEE) and take into account the specifics of this region. Thus, this study is also a departure from the recent analyses that investigated the impact of the euro area crisis on sovereign credit risk, though mostly they focused on the „old“ EU member states. Second, building on Reusens and Croux (2017), who provide evidence that the CRAs changed their assessment after the outbreak of the euro area crisis, we investigate the factors determining the sovereign credit ratings in the period $2013 q 1-2018 q 4$, when the highest tensions in the euro area were receding, compared to the pre-crisis $(2004 q 1-2008 q 2)$ and crisis periods (2008q3 - 2012q4). Third, we investigate if and how merely using the euro - alongside the „traditional“ set of quantitative and qualitative factors - has influenced the sovereign credit ratings of the ,new“ EU member states. Taking the results of previous research (cf. Alexy, Káčer and Ochotnický, 2014 or Wilson, Ochotnicky and Kacer, 2014), which indicates that euro area membership is associated with higher ratings in CEE countries, we aim to check whether this positive relationship also persisted during the crisis and in the postcrisis years, after substantial changes in the institutional framework of the euro area were introduced.

The remainder of this paper is as follows. Section 1 provides a literature review related to the determinants of sovereign credit ratings. Section 2 briefly describes the rating systems of S\&P, Moody's, and Fitch, and the variables used as explanatory variables in our study. Section 3 presents our empirical methodology. In Section 4, we discuss the empirical results. The last Section concludes.

\section{Literature Review}

The literature on the determinants of sovereign credit ratings is substantial. Different determinants have been identified depending on (the groups of) countries and time periods considered, as well as estimation methods used. Below, the most important bodies of research will be presented. Needless to say, the evolution of threads taken is closely related to the changing developments in the global economy, with the impact of the global financial crisis of 2007/2008 dominating the most recent studies.

The initial research concentrated mainly on the macroeconomic determinants of sovereign credit ratings. The first systematic study was conducted by Cantor and Packer (1996), who found the significance of six variables: per capita income, GDP growth, inflation, external debt, level of economic development, and default history. Subsequent studies largely confirmed Cantor and Packer's findings and/or pointed to a slightly larger role of external variables (cf. Monfort and Mulder, 2000; Afonso, 2003; Bissoondoyal-Bheenick, 2005). 
Over time, more and more attention was given to institutional and political factors as potential explanatory variables. For example, Mellios and Paget-Blanc (2006), next to nine macroeconomic factors, identify the important role of the corruption index interpreted as an indicator of governance quality. Afonso, Gomes and Rother (2011) provide evidence for the significance of government effectiveness as a long-term determinant. Governance turns out to be significant in the study of Erdem and Varli (2014), whereas it is the European Economic Policy Uncertainty Index in the study of Boumparis, Milas and Panagiotidis (2017). Teixeira et al. (2018) find that both the corruption index and the political stability index might exert an important impact on ratings.

In the aftermath of the 2008/2009 global financial crisis, research interest turned to the factors that reflect financial system stability, which were rarely accounted for in the studies carried out prior to the crisis. The results of this strand of the literature show that these factors play an important, additional role in shaping sovereign credit ratings. For example, Boumparis, Milas and Panagiotidis (2019) identify a feedback loop between the ratings and banking risk factor approximated by non-performing loans (NPLs). Sehgal et al. (2018) employ domestic credit to the private sector by banks (\% of GDP) to measure the size of the banking system and demonstrate that countries with larger banking systems are likely to have lower sovereign risk assessments. Chari et al. (2019) introduce a new metric of the expected joint loss of the banking sector in the event of a large financial meltdown (JLoss) and show that there is a negative correlation between the metric and sovereign credit ratings.

Further, an important conclusion stemming from a large number of studies is that the determinants of sovereign credit ratings vary depending on the level of the country's economic development or its membership in a given economic integration group. Taking into account the European context only, Miricescu, Ţâtu and Cornea (2016) investigate the determinants of sovereign credit ratings of $25 \mathrm{EU}$ countries over the period 2005 - 2012. They show that the ratings of the EU-15 advanced economies largely depend on real GDP growth, GDP per capita, unemployment, and current account balance, whereas those of the ten transition countries of CEE are more sensitive to public debt, inflation and corruption control. Alexy, Káčer and Ochotnický (2014) contribute to the literature by measuring the impact of EU and euro area membership on sovereign risk assessment of the Visegrad Four countries. They provide evidence that joining the ranks of the EU, as well as adopting the euro, improved the ratings of those countries. Similar results for individual rating agencies were obtained by Wilson, Ochotnicky and Kacer (2014), who investigated 13 EU countries from the CEE region and Turkey. However, in another study, Reusens and Croux (2017) indicate that using the common currency worked to the advantage of the euro area members only in the 
pre-crisis period. After the outbreak of the European debt crisis in 2009, the effect switched from positive to negative. Further, the findings of Boumparis, Milas and Panagiotidis (2017) point to heterogeneities in the euro area itself. In particular, GDP per capita remains the key variable for high-rated countries, whereas competitiveness and regulatory quality play a larger role for lower-rated ones.

Finally, different authors employed alternative econometric tools to investigate the relationship between sovereign ratings and their determinants. In particular, two approaches have been dominant. The early studies applied linear regression techniques that assume the cardinality of the sovereign ratings (cf. Cantor and Packer, 1996; Afonso, 2003; Connolly, 2007). Over time, this approach came under criticism, as more and more researchers questioned the assumption of an equal distance between any two adjacent categories of rating (e.g., a difference between AAA and AA+ seems "smaller" than a difference between BBB- and $\mathrm{BB}+)$. Hence, to address this controversy, the use of ordered response models, which assume that sovereign ratings represent an ordinal ranking of creditworthiness, has become more common (cf. Afonso, Gomes and Rother, 2011; Erdem and Varli, 2014; Tennant, Tracey and King, 2018).

The summary of the assumptions, i.e., countries considered, sample period, methodology, and key rating-drivers identified in the papers discussed here are presented in Table 1.

Table 1

Overview of Existing Literature on Sovereign Credit Rating Determinants

\begin{tabular}{|c|c|c|c|c|}
\hline Study & Dataset & $\begin{array}{l}\text { Sample } \\
\text { period }\end{array}$ & Methodology* & $\begin{array}{c}\text { Explanatory variables } \\
\text { with significant influence }\end{array}$ \\
\hline $\begin{array}{l}\text { Cantor and } \\
\text { Packer } \\
(1996)\end{array}$ & 49 countries & $\begin{array}{l}\text { Ratings as of } \\
29 \text { September } \\
1995\end{array}$ & OLS & $\begin{array}{l}\text { Per capita income, GDP growth, } \\
\text { inflation, external debt, level of } \\
\text { economic development, default history }\end{array}$ \\
\hline $\begin{array}{l}\text { Monfort and } \\
\text { Mulder } \\
(2000)\end{array}$ & $\begin{array}{l}20 \text { emerging } \\
\text { economies }\end{array}$ & $1995-1999$ & $\begin{array}{l}\text { Dynamic panel } \\
\text { model }\end{array}$ & $\begin{array}{l}\text { Debt/exports, debt rescheduling, fiscal } \\
\text { balance, GDP growth, inflation, TOT, } \\
\text { export growth rate, investment/GDP }\end{array}$ \\
\hline $\begin{array}{l}\text { Afonso } \\
(2003)\end{array}$ & $\begin{array}{l}81 \text { countries } \\
(29 \text { developed } \\
\text { and } 52 \\
\text { developing) }\end{array}$ & $\begin{array}{l}\text { Ratings in } \\
\text { June } 2001\end{array}$ & Ols & $\begin{array}{l}\text { GDP per capita, external debt } \\
\text { to exports ratio, level of economic } \\
\text { development, default history, real } \\
\text { growth rate, inflation rate }\end{array}$ \\
\hline $\begin{array}{l}\text { Bissoondoyal- } \\
\text { Bheenick } \\
(2005)\end{array}$ & 95 countries & \begin{tabular}{|l|} 
December \\
$1995-$ \\
December \\
1999 \\
\end{tabular} & $\begin{array}{l}\text { Ordered probit } \\
\text { model }\end{array}$ & $\begin{array}{l}\text { GNP per capita, inflation (in addition, } \\
\text { CA balance and level of foreign } \\
\text { reserves for a subsample of low rated } \\
\text { countries) }\end{array}$ \\
\hline $\begin{array}{l}\text { Mellios and } \\
\text { Paget-Blanc } \\
(2006)\end{array}$ & 86 countries & $\begin{array}{l}\text { Ratings on } \\
31 \text { december } \\
2003\end{array}$ & $\begin{array}{l}\text { Ordered logit } \\
\text { model }\end{array}$ & $\begin{array}{l}\text { Per capita income, government } \\
\text { income, changes in real exchange rate, } \\
\text { inflation rate, default history, } \\
\text { corruption index }\end{array}$ \\
\hline $\begin{array}{l}\text { Connolly } \\
(2007)\end{array}$ & 52 countries & $1993-2002$ & $\begin{array}{l}\text { Pooled Two-Stage } \\
\text { Least Squares } \\
\text { regression, } \\
\text { Generalized } \\
\text { Two-Stage Least } \\
\text { Squares regression }\end{array}$ & $\begin{array}{l}\text { GDP per capita, growth in GDP, } \\
\text { previous default, corruption perception } \\
\text { index }\end{array}$ \\
\hline
\end{tabular}




\begin{tabular}{|c|c|c|c|c|}
\hline \begin{tabular}{|l} 
Afonso \\
et al. (2011)
\end{tabular} & $\begin{array}{l}66 \text { countries } \\
\text { for Moody's, } \\
65 \text { for S\&P, } \\
58 \text { for Fitch }\end{array}$ & $1995-2005$ & $\begin{array}{l}\text { Linear regression, } \\
\text { ordered probit } \\
\text { model, random } \\
\text { effects ordered } \\
\text { probit }\end{array}$ & $\begin{array}{l}\text { Short-run determinants: GDP per } \\
\text { capita, real GDP growth, government } \\
\text { debt, government deficit; long-run } \\
\text { determinants: government } \\
\text { effectiveness, external debt, foreign } \\
\text { reserves, sovereign default dummies }\end{array}$ \\
\hline $\begin{array}{l}\text { Erdem and } \\
\text { Varli (2014) }\end{array}$ & $\begin{array}{l}8 \text { emerging } \\
\text { markets }\end{array}$ & $2002-2011$ & $\begin{array}{l}\text { Linear regression, } \\
\text { ordered response } \\
\text { models }\end{array}$ & $\begin{array}{l}\text { Budget balance/GDP, GDP per capita, } \\
\text { governance indicators, reserves/GDP, } \\
\text { external debt/export }\end{array}$ \\
\hline $\begin{array}{l}\text { Alexy et al. } \\
(2014)\end{array}$ & $\begin{array}{l}\text { Visegrad Four } \\
\text { countries }\end{array}$ & $1993-2012$ & $\begin{array}{l}\text { Linear model with } \\
\text { fixed effects }\end{array}$ & $\begin{array}{l}\text { Inflation, unemployment, broad money } \\
\text { to GDP, import to export, openness } \\
\text { of the economy, government gross } \\
\text { debt, primary balance, size of the } \\
\text { government, voice and accountability } \\
\text { score of Worldwide Governance } \\
\text { Indicators, EU and EMU membership }\end{array}$ \\
\hline \begin{tabular}{|l} 
Wilson \\
et al. (2014)
\end{tabular} & $\begin{array}{l}13 \mathrm{EU} \\
\text { countries } \\
\text { from the CEE } \\
\text { region and } \\
\text { Turkey }\end{array}$ & $1993-2012$ & $\begin{array}{l}\text { Linear model with } \\
\text { random effects, } \\
\text { ordered probit, } \\
\text { ordered probit } \\
\text { with random } \\
\text { effects }\end{array}$ & $\begin{array}{l}\text { Per capita GDP and gross debt } \\
\text { (for all equations), real GDP growth, } \\
\text { government size, inflation, foreign } \\
\text { reserves to imports, external balance, } \\
\text { primary balance, EU and EMU } \\
\text { dummies (in individual equations), } \\
\text { crisis dummy }\end{array}$ \\
\hline $\begin{array}{l}\text { Miricescu } \\
\text { et al. (2016) }\end{array}$ & $\begin{array}{l}25 \mathrm{EU} \\
\text { countries }\end{array}$ & $2005-2012$ & $\begin{array}{l}\text { Linear model with } \\
\text { random effects }\end{array}$ & $\begin{array}{l}\text { Inflation, unemployment, public debt } \\
\text { to GDP ratio, real growth rate, GDP } \\
\text { per capita, control of corruption, CA }\end{array}$ \\
\hline $\begin{array}{l}\text { Boumparis } \\
\text { et al. (2017) }\end{array}$ & $\begin{array}{l}19 \text { Eurozone } \\
\text { countries }\end{array}$ & $2002-2015$ & Quantile regression & $\begin{array}{l}\text { GDP per capita, government debt, CA } \\
\text { balance, inflation rate, unemployment } \\
\text { rate, regulatory quality, } \\
\text { competitiveness indicator, EPU }\end{array}$ \\
\hline \begin{tabular}{|l|} 
Reusens \\
and Croux \\
(2017)
\end{tabular} & 90 countries & $2002-2015$ & $\begin{array}{l}\text { Multivariate } \\
\text { ordered probit } \\
\text { model }\end{array}$ & $\begin{array}{l}\text { Fiscal balance, economic development, } \\
\text { external debt, Eurozone membership, } \\
\text { GDP growth, government debt, as well } \\
\text { as the interaction of the last two } \\
\text { variables, inflation, default history }\end{array}$ \\
\hline \begin{tabular}{|l|} 
Sehgal \\
et al. (2018)
\end{tabular} & 135 countries & $2008-2012$ & $\begin{array}{l}\text { Ordered logit } \\
\text { and probit model }\end{array}$ & $\begin{array}{l}\text { Economic strength indicators, inflation, } \\
\text { governance indicators, fiscal strength } \\
\text { indicators, domestic political risk, size } \\
\text { of the banking system }\end{array}$ \\
\hline \begin{tabular}{|l|} 
Teixeira \\
et al. (2018)
\end{tabular} & 86 countries & $1993-2013$ & $\begin{array}{l}\text { Ordered probit } \\
\text { model }\end{array}$ & $\begin{array}{l}\text { GDP per capita, GDP growth, } \\
\text { unemployment, inflation, investment/ } \\
\text { GDP, external debt/GDP, liquidity } \\
\text { risk, CA balance, government debt, } \\
\text { default history, corruption index, } \\
\text { political stability index, regional } \\
\text { dummy variables, dummy variables } \\
\text { associated with the Asian crisis and } \\
\text { the recent international financial crisis }\end{array}$ \\
\hline \begin{tabular}{|l} 
Tennant \\
et al. (2018)
\end{tabular} & 132 countries & $1996-2011$ & $\begin{array}{l}\text { Ordered probit } \\
\text { model }\end{array}$ & $\begin{array}{l}\text { Debt stock, debt service, GDP per } \\
\text { capita, investment, exports of goods } \\
\text { and services, total reserves in months } \\
\text { of imports, CA balance, inflation, } \\
\text { domestic credit, institutional quality, } \\
\text { default history, binary variables related } \\
\text { to the countries' development level }\end{array}$ \\
\hline \begin{tabular}{|l|} 
Boumparis \\
et al. (2019)
\end{tabular} & 72 countries & $1998-2016$ & VAR & $\begin{array}{l}\text { Uncertainty, GDP growth rate, } \\
\text { investments, government debt, fiscal } \\
\text { balance, NPLs }\end{array}$ \\
\hline \begin{tabular}{|l|}
$\begin{array}{l}\text { Chari et al. } \\
(2019)\end{array}$ \\
\end{tabular} & $\begin{array}{l}19 \text { emerging } \\
\text { economies }\end{array}$ & \begin{tabular}{|l|}
$1999 \mathrm{q} 1-$ \\
$2017 \mathrm{q} 3$ \\
\end{tabular} & $\begin{array}{l}\text { OLS with robust } \\
\text { standard errors }\end{array}$ & $\begin{array}{l}\text { JLoss, GDP per capita, U.S. Treasury } \\
\text { rate, on/off-the-run spread }\end{array}$ \\
\hline
\end{tabular}

Note: * In each case where the authors included more than one country and more than one period, panel estimation techniques were used.

Source: Authors' own compilation. 


\section{Data}

\subsection{Credit Rating Systems and the Response Variable}

We use quarterly data from $2004 \mathrm{q} 1$ to $2018 \mathrm{q} 4$ for nine countries that joined the EU in 2004 (Czechia, Estonia, Hungary, Latvia, Lithuania, Malta, Poland, Slovakia, and Slovenia). Our dependent variable is the sovereign credit rating ascribed by the three most influential rating agencies, i.e., S\&P, Fitch, and Moody's.

S\&P distinguishes four main credit rating scales: A, B, C, and D. „AAA“ is the highest rating and indicates an obligor's ,extremely strong capacity to meet its financial commitments“. ,SD“ and „D“ are the lowest credit ratings. The first is assigned when an obligor is believed to have selectively defaulted on part of its financial obligations. An obligor rated „D“ is believed to fail to meet (substantially) all of its obligations in a timely manner. To differentiate among issuers in the same category, S\&P uses plus (+) and (-) signs. This applies to ratings from AA to CCC categories. ${ }^{2}$ A very similar credit rating system is used by Fitch. ${ }^{3}$ When it comes to Moody's, it employs three main designations: A, B, and C. „Aaa“ is its highest grade and „C“ is the lowest. Moody's also applies numeric modifiers, 1, 2 and 3, to generic rating categories from Aa through Caa, indicating the higher end, a mid-range ranking, and the lower end of a given category, respectively. ${ }^{4}$

Moreover, all three rating agencies have adopted a system of rating outlooks, which indicate the potential direction of a rating change over the medium term (typically, from six months to two years). In particular, a positive (negative) outlook indicates an upward (downward) trend on a rating scale, while a stable outlook indicates a low likelihood of a rating action over the medium term.

We collected the S\&P, Fitch and Moody's long-term sovereign credit ratings and outlooks from the Thomson Reuters Eikon database. We use a linear transformation of the ratings to a numerical scale, where 1 corresponds to the lowest sovereign risk assessment (,SD/D“ for S\&P, „RD/D“ for Fitch, and „C“ for Moody's) and 21 corresponds to the highest (,AAA“ for S\&P and Fitch, and „Aaa“ for Moody's; cf. Table 2).

\footnotetext{
${ }^{2}<$ https://www.standardandpoors.com/en_EU/web/guest/article/-/view/sourceId/504352>; Retrieved July 22, 2020.

${ }^{3}<$ https://www.fitchratings.com/research/fund-asset-managers/ratings-definitions-26-03-2020>; Retrieved July 22, 2020.

${ }^{4}<$ https://www.moodys.com/sites/products/productattachments/ap075378_1_1408_ki.pdf>; Retrieved July 28, 2020.
} 
The difference between two adjacent ratings is always equal to one. As we also include outlooks, in the case of a positive (negative) outlook, $1 / 3$ is added to (subtracted from) the numerical value assigned to a given rating. To give an example, a „BB“ rating (on S\&P and Fitch scales) with a positive outlook will amount to $10^{1 / 3}$, while a „BB“ rating with a negative outlook will amount to $92 / 3$. Finally, to allow for greater variability, we compute the dependent variable as the average of the daily observations of numerically expressed ratings and outlooks in a given quarter.

Ta b le 2

\section{S\&P, Fitch and Moody's Credit Ratings and Linear Transformation}

\begin{tabular}{|c|c|c|c|c|c|}
\hline & Rating description & $\mathbf{S \& P}$ & Fitch & Moody's & Transformation \\
\hline \multirow{10}{*}{ 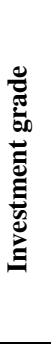 } & Prime & AAA & AAA & Aaa & 21 \\
\hline & \multirow{3}{*}{ High grade } & $\mathrm{AA}+$ & AA+ & Aa1 & 20 \\
\hline & & AA & AA & $\mathrm{Aa} 2$ & 19 \\
\hline & & AA- & AA- & $\mathrm{Aa} 3$ & 18 \\
\hline & \multirow{3}{*}{ Upper medium grade } & $\mathrm{A}+$ & A+ & A1 & 17 \\
\hline & & A & A & $\mathrm{A} 2$ & 16 \\
\hline & & A- & A- & A3 & 15 \\
\hline & \multirow{3}{*}{ Lower medium grade } & $\mathrm{BBB}+$ & $\mathrm{BBB}+$ & Baal & 14 \\
\hline & & $\mathrm{BBB}$ & BBB & $\mathrm{Baa} 2$ & 13 \\
\hline & & BBB- & BBB- & $\mathrm{Baa} 3$ & 12 \\
\hline \multirow{11}{*}{ 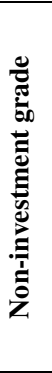 } & \multirow{3}{*}{$\begin{array}{l}\text { Non-investment grade } \\
\text { speculative }\end{array}$} & $\mathrm{BB}+$ & $\mathrm{BB}+$ & Ba1 & 11 \\
\hline & & BB & BB & $\mathrm{Ba} 2$ & 10 \\
\hline & & $\mathrm{BB}-$ & $\mathrm{BB}-$ & $\mathrm{Ba} 3$ & 9 \\
\hline & \multirow{3}{*}{ Highly speculative } & $\mathrm{B}+$ & $\mathrm{B}+$ & B1 & 8 \\
\hline & & $\mathrm{B}$ & B & B2 & 7 \\
\hline & & $\mathrm{B}-$ & $\mathrm{B}-$ & B3 & 6 \\
\hline & \multirow{3}{*}{ Substantial risks } & $\mathrm{CCC}+$ & $\mathrm{CCC}+$ & Caa1 & 5 \\
\hline & & $\mathrm{CCC}$ & $\mathrm{CCC}$ & $\mathrm{Caa} 2$ & 4 \\
\hline & & $\mathrm{CCC}-$ & $\mathrm{CCC}-$ & $\mathrm{Caa} 3$ & 3 \\
\hline & Extremely speculative & $\mathrm{CC}$ & $\mathrm{CCC}$ & $\mathrm{Ca}$ & 2 \\
\hline & Default & SD/D & $\mathrm{RD} / \mathrm{D}$ & $\mathrm{C}$ & 1 \\
\hline
\end{tabular}

Source: Authors' own compilation based on the S\&P, Fitch and Moody's websites and <https://countryeconomy.com/ratings>; Retrieved 3 August 2020.

\subsection{Explanatory Variables}

Building upon the previous literature, our set of potential explanatory variables consists of quantitative (macroeconomic) and qualitative variables, whose breakdown is presented in Table 3..$^{5}$ Appendix $\mathrm{A}^{6}$ includes a detailed description of the individual explanatory variables and their sources (Table 14), as well as basic descriptive statics for each country considered (Table 15).

\footnotetext{
${ }^{5}$ Macroeconomic variables are further divided into those in the realm of fiscal-monetary policy mix and external variables.

${ }^{6}$ Available at: <https://www.sav.sk/journals/uploads/0624113506\%2021\%20StawaszGrabowska\%20online\%20appendices.pdf>.
} 
T a b le 3

Explanatory Variables

\begin{tabular}{|l|l|l|}
\hline \multicolumn{2}{|c|}{ Quantitative (macroeconomic) variables } & \multicolumn{1}{|c|}{ Qualitative variables } \\
\hline \multicolumn{1}{|c|}{ Policy mix } & \multicolumn{1}{|c|}{ External } & \\
\hline Fiscal balance & CA (current account balance) & Corruption \\
Fiscal balance $^{\mathrm{p}}$ & External debt & Governance \\
GDP growth & Reserves & EPU (Economic Policy Uncertainty Index) \\
GDP growth & & VIX (CBOE Volatility Index) \\
Government debt & & \\
Inflation & & \\
Investment & & \\
Private debt & & \\
Unemployment & & \\
\hline
\end{tabular}

Source: Authors' own compilation.

For each variable, the expected sign of parameter estimate is motivated as follows.

Fiscal balance. Large fiscal deficits reduce the country's savings and indicate macroeconomic disequilibria (Afonso et al., 2011; Stubelj and Dolenc, 2010). The expected sign of the estimate of the parameter for Fiscal balance is positive.

Fiscal balance $e^{p}$ - projected (1 year ahead) fiscal balance as a percentage of GDP. The inclusion of the projected fiscal budget to GDP, alongside the current readings, aims to reflect the forward-looking behaviour of financial market participants. The expected sign of the estimate of the parameter for Fiscal balance ${ }^{p}$ is positive.

GDP growth. Positive GDP growth is conducive to the fulfilment of payment obligations. In turn, along with a decline in economic growth, the government's ability to collect taxes decreases, making it difficult to service debt. Consequently, country risk assessment may deteriorate. Thus, the expected sign of the estimate of the parameter for this variable is positive. At the same time, it should be noted that an increase in debt is not likely to lead to greater financial risk if it is slower than GDP growth.

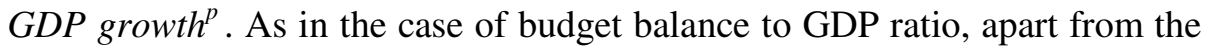
actual readings, the forecast for GDP is included. The proposed approach takes the forward-looking behaviour of financial markets into account. The expected sign of the estimate of the parameter for the GDP growt $^{p}$ variable is positive.

Government debt. A higher level of government debt entails a higher probability of default and liquidity problems. Therefore, the expected sign of the estimate of the parameter for this variable is negative.

Inflation. High inflation often results from mistakes at the level of economic management, and the monetary financing of deficits, in particular. It severely hampers economic agents' decision-making process, leads to inhabitants' dissatisfaction, and can even cause political instability. Furthermore, a high inflation 
rate undermines the country's competitiveness in comparison with its trading partners, which particularly applies to members of a currency union as they cannot resort to devaluing their national currency. Thus, the expected sign of the estimate of the parameter for the Inflation variable is negative. At the same time, the negative effect might be partially mitigated as higher inflation reduces the real stock of public debt in domestic currency (Reusens and Croux, 2017).

Investment. The higher the level of investment in a given country, the higher its prospects for future growth. We expect a positive effect of this variable on credit ratings.

Private debt. Private sector debt to GDP measures the indebtedness of the sectors of non-financial corporations and households and non-profit institutions serving households, as a percentage of GDP. Private indebtedness started to be closely monitored after the outbreak of the 2007/2008 crisis, when many countries experienced a negative feedback loop between the condition of their private sector and public finances. Hence, we decided to include Private debt, and we expect a negative impact of this variable on credit ratings.

Unemployment. A country with lower unemployment has a more efficient labour market. The lower the unemployment, the higher the overall taxable income and the lower the fiscal burden for unemployment subsidies. Therefore, a negative sign of the parameter estimate is expected.

Current Account (CA). In the case of the analysed variable, the direction of its impact on credit rating is ambiguous. The current account surplus/deficit is a measure of the country's international competitiveness. Countries that record high current account deficits are seen as less competitive in terms of exports. Moreover, CA deficits indicate the dependence of both the private and public sectors on external creditors, which may threaten the country's sustainability in the longer term. Given the above, the positive estimate of the parameter for $C A$ can be expected. On the other hand, if higher CA deficits reflect the rapid accumulation of investment, then a reverse sign of the estimate of the parameter can be expected.

External debt. Overreliance on external debt can undermine the creditworthiness of a sovereign. It raises the risk of additional fiscal burden, either directly (when debt is incurred by the public sector) or indirectly (due to a possible engagement of public funds to support over-indebted domestic private sector). Hence, the expected sign of the corresponding parameter estimate is negative.

Reserves. Reserves are measured as total reserves, including gold, in months of imports of goods and services they could pay for. The expected effect on a country's rating is positive, as high reserves indicate that there are more funds available for debt payments. 
Corruption. Higher corruption renders the economic environment less predictable and casts doubts over the country's capability to pay off its debts. To proxy for corruption, we use the Corruption Perceptions Index provided by Transparency International. The values of the index range from 0 (highly corrupt) to 100 (very clean). Therefore, we expect a positive sign of the corresponding parameter estimate.

Governance. The quality of governance is measured as an average of 5 indicators provided by the World Bank, i.e., voice and accountability, political stability and the absence of violence, government effectiveness, regulatory quality, and rule of law. ${ }^{7}$

There are several channels via which the quality of governance can impact a sovereign credit rating. For example, Tennant, Tracey and King (2018) highlight the role of government effectiveness, regulatory quality and rule of law as indicators reflecting a country's capability to formulate and implement sound policies, and its respect for the institutions that govern economic interaction. Better regulatory quality also seems conducive to generating higher tax revenues as the government is better able to detect and counter tax evasion (Eichler, 2014). Interestingly, for the specific context of the euro area sovereign debt crisis, Boysen-Hogrefe (2017) uses a composite World Bank indicator on the quality of governance as a proxy for a country's ability to overcome economic crises. All in all, we expect a positive sign of the corresponding parameter, as better quality governance should promote fiscal sustainability and, thus, reduce sovereign default risks.

$E P U$. The index of European-wide EPU measures the level of economic policy uncertainty in Europe. Its values depend on the number of articles from 10 leading European newspapers containing the terms uncertain or uncertainty, economic or economy, as well as one or more policy-relevant terms. The higher the level of uncertainty, the more likely the economic agents are to withhold their investment and consumption decisions, thus deteriorating the growth prospects. Therefore, we expect a negative impact of EPU on the credit ratings.

VIX. VIX, the CBOE volatility index, is a measure of the implied volatility of the S\&P 500 index. It is often used to describe uncertainty and risk aversion in the global financial markets (cf. Giordano, Pericoli and Tommasino, 2013; Kilponen, Laakkonen and Vilmunen, 2015; Afonso et al., 2018). We expect a negative effect of VIX on a country's rating, also in light of conclusions stemming from recent studies that CRAs tend to favour developed economies at the

\footnotetext{
${ }^{7}$ We decided not to include a control for corruption, which is the sixth index reported by the World Bank, as this dimension of governance is already captured by the variable Corruption.
} 
expense of emerging markets (Luitel, Vanpée and De Moor, 2016; De Moor, 2018; Tennant, Tracey and King, 2018).

Finally, we also add the $E M U$ variable, which adopts a value of 1 for the euro area countries from the quarter that they entered the common currency area onwards, and 0 otherwise.

\section{Econometric Methodology}

We use a panel of nine out of the ten countries that joined the EU in 2004, namely: Czechia, Estonia, Hungary, Latvia, Lithuania, Malta, Poland, Slovakia, and Slovenia. Cyprus was not included due to missing data. The sample period runs from 2004q1 until 2018q4. The lower boundary applies to the year of accession to the EU by the countries under consideration. The upper boundary was conditional on the availability of data at the time of the study. The frequency of data is quarterly.

In order to evaluate the impact of macroeconomic and qualitative variables on credit ratings, we consider the estimation of the parameters of the following panel regression model:

$$
R A T_{i t}=\boldsymbol{x}_{i t} \boldsymbol{\beta}+\varepsilon_{i t}
$$

where $R A T_{i t}$ denotes the value of a credit rating for the $i$-th country in period $t$, and $\boldsymbol{x}_{i t}$ is the vector of explanatory variables, $\boldsymbol{\beta}$ is the vector of parameters and $\varepsilon_{i t}$ denotes the error term. We use the F-test, and the Hausman test in order to choose one of three panel data models (pooled regression, fixed effects model, random effects model). The results of testing for the presence of effects indicate that the panel model with fixed effects is appropriate to explain the performance of credit ratings in the analysed EU member states (cf. Section 5). In the next step, we test whether autocorrelation occurs. The results of the Breusch-Godfrey test (cf. Hajria, Khardani and Raïssi, 2018) indicate that autocorrelation exists (cf. Section 5).

To deal with this problem, we estimate the parameters of the fixed effects panel model with robust standard errors. Using the strategy ,from general to specific" (Charemza and Deadman, 2003), we select variables that affect the rating level. Variables significant at the 0.05 level of significance are selected as the rating determinants. ${ }^{8}$

\footnotetext{
${ }^{8}$ For greater transparency, Appendix B (Availabe at: <https://www.sav.sk/journals/uploads/0624113506\%2021\%20Stawasz-

Grabowska\%20online\%20appendices.pdf $>$ ) presents the results of unrestricted estimations (i.e. with the starting set of explanatory variables before the exclusion of those variables which turned out not to be significant at the 0.05 level).
} 


\section{Estimation Results and Discussion}

Firstly, in order to address the potential multicollinearity problem, we perform a multicollinearity check using variance inflation factors (VIFs). The results of this check are presented in Table 4. As can be seen, External debt and $G D P$ growth $^{p}$ are the only variables with VIF higher than 5. Hence, they will not be included in our starting set of explanatory variables.

Ta b le 4

Results of Multicollinearity Testing with the Use of VIFs

\begin{tabular}{|l|c|}
\hline Variable & Centred VIF \\
\hline CA & 2.218 \\
External debt & 6.594 \\
Fiscal balance & 2.385 \\
Fiscal balancep & 3.538 \\
GDP growth & 3.869 \\
GDP growth & 5.331 \\
Government debt & 2.913 \\
Inflation & 1.870 \\
Investment & 3.241 \\
Private debt & 2.026 \\
Unemployment & 2.117 \\
Reserves & 3.162 \\
Corruption & 2.459 \\
Governance & 2.378 \\
EPU & 1.873 \\
VIX & 1.664 \\
EMU & 4.119 \\
\hline
\end{tabular}

Source: Authors' own calculations.

In the next step, an appropriate panel data model should be selected. The presence of fixed effects is tested based on the F-test. The selection between fixed effects and random effects model is conducted based on the Hausman test. The results of the testing are presented in Table 5 .

Table 5

Testing for the Presence of Fixed and Random Effects

\begin{tabular}{|l|c|c|}
\hline Testing & Statistic & p-value \\
\hline Presence of fixed effects & 167.43 & 0.000 \\
Model with fixed versus random effects & 5.85 & 0.664 \\
\hline
\end{tabular}

Source: Authors' own calculations.

Ta b l e 6

The Results of the Breusch-Godfrey Test for Autocorrelation

\begin{tabular}{|l|c|c|}
\hline Period & Statistic & p-value \\
\hline $2004 \mathrm{q} 1-2018 \mathrm{q} 4$ & 419.71 & 0.000 \\
\hline
\end{tabular}

Source: Authors' own calculations. 
The results from Table 5 indicate that the model with fixed effects is the best solution. Due to the problem of autocorrelation (cf. Table 6), a model with robust standard errors is applied. Table 7 presents the estimation results.

T a b l e 7

Results of the Estimation of the Parameters of the Fixed Effects Model with Robust Standard Errors

\begin{tabular}{|l|c|c|c|}
\hline Variable & Estimate & Standard error & p-value \\
\hline Constant & 13.933 & 0.169 & 0.000 \\
CA & -0.038 & 0.007 & 0.000 \\
Government debt & -0.067 & 0.003 & 0.000 \\
Inflation & -0.039 & 0.012 & 0.001 \\
Unemployment & -0.085 & 0.009 & 0.000 \\
Governance & 5.143 & 0.175 & 0.000 \\
EMU & 0.917 & 0.078 & 0.000 \\
\hline $\mathrm{R}^{2}=0.875$ & & \\
$\mathrm{~N}=540$ & & \\
F-statistic $=262.828$ \\
p-value $=0.000$
\end{tabular}

Source: Authors' own calculations.

Only the variables that turned out to be significant at the level of 0.05 are included in the final specification. As a robustness check, the parameters of the model with lagged explanatory variables are estimated and are presented in Table 8 .

Table 8

Results of the Estimation of the Parameters with Lagged Explanatory Variables

\begin{tabular}{|l|c|c|c|}
\hline Variable & Estimate & Standard error & p-value \\
\hline Constant & 14.232 & 0.210 & 0.000 \\
CA & -0.037 & 0.007 & 0.000 \\
Fiscal balance & 0.047 & 0.017 & 0.007 \\
Government debt & -0.067 & 0.003 & 0.000 \\
Inflation & -0.053 & 0.012 & 0.000 \\
Private debt & -0.005 & 0.002 & 0.026 \\
Unemployment & -0.064 & 0.013 & 0.000 \\
Governance & 5.285 & 0.219 & 0.000 \\
EMU & 0.846 & 0.081 & \\
\hline $\mathrm{R}^{2}=0.871$ & & \\
$\mathrm{~N}=531$ & & & \\
F-statistic $=217.458$ & & & \\
p-value $=0.000$ &
\end{tabular}

Source: Authors' own calculations.

Only the variables that turned out to be significant at the level of 0.05 are included in the final specification. When lagged explanatory variables are included, the estimates of the parameters are similar and have a statistically significant impact on the dependent variable. At the same time, the model with lagged variables points to a larger number of rating determinants, as Fiscal balance $e^{p}$ and Private debt also play an important role. 
In the next step, we decided to check whether the role of individual explanatory variables differed over the period under consideration. To this end, three sub-periods were identified: • the pre-crisis period $(2004 q 1-2008 q 2) \bullet$ the crisis period $(2008 q 3-2012 q 4) \cdot$ the post-crisis period $(2013 q 1-2018 q 4)$.

The demarcation between the first and the second sub-period is marked by the collapse of Lehman Brothers, which took place in the third quarter of 2008. The post-crisis period starts in 2013q1 after the announcements related to the Outright Monetary Transactions (henceforth OMT) by the European Central Bank (henceforth ECB). The launch of this measure was widely associated with the ECB's acceptance of the role of lender of last resort for the euro area sovereigns (cf. De Grauwe and Ji, 2014; Winkler, 2015), and since then a substantial reduction in tensions in the euro area has been observed. Similar periodisation has been used in the extensive literature on the sovereign bond yields of the euro area countries (cf. Boysen-Hogrefe, 2017; Ehrmann and Fratzscher, 2017; Afonso et al. 2018). Table 9 presents the results of testing the stability of parameters between the three sub-periods based on the Chow breakpoint test.

Table 9

Results of Testing the Stability of Parameters Based on the Chow Breakpoint Test

\begin{tabular}{|l|c|c|}
\hline Sub periods & F statistic & p-value \\
\hline $1^{\text {st }}$ and $2^{\text {nd }}$ sub-period & 69.025 & 0.000 \\
$2^{\text {nd }}$ and $3^{\text {rd }}$ sub-period & 51.382 & 0.000 \\
\hline
\end{tabular}

Source: Authors' own calculations.

The results indicate that the parameters are not stable, and separate estimations in three sub-periods are reasonable. As with the model for the whole period, autocorrelation is tested using the Breusch-Godfrey test. The results are presented in Table 10. Due to the presence of autocorrelation, panel models with fixed effects and robust standard errors are estimated. The results are presented in Tables 11 through 13.

T a b l e 10

The Results of the Breusch-Godfrey Test for Autocorrelation for Three Subperiods

\begin{tabular}{|l|c|c|}
\hline Period & Statistic & p-value \\
\hline $2004 \mathrm{q} 1-2008 \mathrm{q} 2$ & 78.137 & 0.000 \\
$2008 \mathrm{q} 3-2012 \mathrm{q} 4$ & 85.464 & 0.000 \\
$2013 \mathrm{q} 1-2018 \mathrm{q} 4$ & 100.46 & 0.000 \\
\hline
\end{tabular}

Source: Authors' own calculations.

The variables that were statistically significant (in at least one of the distinguished subperiods) are GDP growth, Government debt, Private debt, Unemployment, Corruption, Governance, EMU, CA, and Inflation. The signs of the 
parameter estimates for these variables are in line with expectations. Hence, the set of the determinants of the sovereign credit ratings of the „new“ EU members is dominated by macroeconomic factors, including those of a domestic and external nature. Moreover, in all sub-periods, the Governance variable proved to be significant, which indicates that the rating agencies attach great importance to the institutional considerations when assessing the creditworthiness of the countries under consideration. Further, our study suggests that the EMU status worked to the advantage of those „new“ EU countries that adopted the common currency, regardless of the economic conditions prevailing in the euro area. Finally, it seems that the ratings were under no influence of global or regional risk factors, as indicated by the insignificance of VIX and EPU. Below, the role of the variables that were statistically significant will be discussed in greater detail.

T a b le 11

\section{Results of the Estimation of the Parameters for the First Sub-period}

\begin{tabular}{|l|c|c|c|}
\hline Variable & Estimate & Standard error & p-value \\
\hline Constant & 16.180 & 0.518 & 0.000 \\
GDP growth & 0.049 & 0.006 & 0.000 \\
Government debt & -0.064 & 0.009 & 0.000 \\
Private debt & -0.011 & 0.003 & 0.000 \\
Unemployment & -0.040 & 0.013 & 0.002 \\
Corruption & 0.025 & 0.006 & 0.000 \\
Governance & 1.605 & 0.493 & 0.001 \\
EMU & 0.650 & 0.112 & 0.000 \\
\hline $\mathrm{R}^{2}=0.954$ & \multicolumn{3}{|}{} \\
$\mathrm{N}=162$ & \multicolumn{3}{|}{} \\
F-statistic $=204.325$ & & \\
p-value $=0.000$ & & \\
\hline
\end{tabular}

Source: Authors' own calculations.

Only the variables that turned out to be significant at the level of 0.05 are included in the final specification.

T a b le 12

Results of the Estimation of the Parameters for the Second Sub-period

\begin{tabular}{|l|c|c|c|}
\hline Variable & Estimate & Standard error & p-value \\
\hline Constant & 14.208 & 0.979 & 0.000 \\
CA & -0.035 & 0.013 & 0.006 \\
GDP growth & 0.024 & 0.010 & 0.021 \\
Government debt & -0.049 & 0.010 & 0.000 \\
Inflation & -0.042 & 0.022 & 0.051 \\
Unemployment & -0.126 & 0.022 & 0.000 \\
Governance & 4.434 & 1.233 & 0.000 \\
EMU & 1.105 & 0.237 & 0.000 \\
\hline $\mathrm{R}^{2}=0.94$ & \multicolumn{3}{|}{} \\
$\mathrm{N}=162$ & & \\
F-statistic $=152.778$ \\
p-value $=0.000$
\end{tabular}

Source: Authors' own calculations. 
Only the variables that turned out to be significant at the level of 0.05 are included in the final specification.

Table 13

Results of the Estimation of the Parameters for the Third Sub-period

\begin{tabular}{|l|c|c|c|}
\hline Variable & Estimate & Standard error & p-value \\
\hline Constant & 16.788 & 0.233 & 0.000 \\
Private debt & -0.029 & 0.003 & 0.000 \\
Unemployment & -0.121 & 0.011 & 0.000 \\
Governance & 2.313 & 0.278 & 0.000 \\
EMU & 0.576 & 0.146 & 0.000 \\
Government debt & -0.014 & 0.006 & 0.016 \\
\hline $\mathrm{R}^{2}=0.982$ & & \\
$\mathrm{~N}=216$ & \multicolumn{3}{|l}{} \\
F-statistic $=847.18$ & & \\
p-value $=0.000$ & & & \\
\hline
\end{tabular}

Source: Authors' own calculations.

Only the variables that turned out to be significant at the level of 0.05 are included in the final specification.

During the research period, we note the importance of macroeconomic factors for country credit ratings. This is particularly evident in the second sub-period, when five fundamental-based variables, i.e., $C A, G D P$ growth, Government debt, Inflation, and Unemployment, proved to be statistically significant. Hence, our results are consistent with previous empirical works offered by the comprehensive literature on country default risk, although they use sovereign bond spreads instead of credit ratings in the regressions (cf. Beirne and Fratzscher, 2013; Giordano, Pericoli and Tommasino, 2013; Grabowski and Stawasz, 2017). The main conclusion from those studies points to a „,wake-up call“ contagion during the euro area sovereign debt crisis, i.e., increased market sensitivity to the macroeconomic fundamentals. Our study indicates that it was not only investors but also CRAs that drew greater attention to fundamental-based factors. This conclusion also pertains to the group of EU countries which were less affected by the crisis.

At the same time, we identify some important differences with regard to the above-mentioned body of research, which very likely stem from the fact that we focus on the „new“ rather than the „old“ EU members. Firstly, our results do not allow us to conclude that macroeconomic fundamentals did not drive the creditworthiness assessment of the "new“ EU countries in the pre-crisis years; rather, they show that the role of those factors increased during the crisis.

Secondly, our study points to other factors that gained in importance during the crisis period. In previous research, they were mainly variables that reflect the sustainability of public finances and economic activity. In this study, they are the Inflation and $C A$ variables, for which we obtain statistical significance only in 
the second sub-period. When it comes to the former, the sign of the corresponding parameter is negative, which is in line with existing literature (Dimitrakopoulos and Kolossiatis, 2015). Similarly, for the group of CEE countries, Miricescu, Ţâtu and Cornea (2016) notice that their sovereign ratings are negatively correlated with inflation rates. Referring to the significance of the analysed variable only in the second sub-period, one can point to relatively high inflation rates at the beginning of this sub-period and the high variability of inflation, particularly in comparison with the post-crisis years.

Turning to the $C A$ variable, in the years leading up to the crisis, the countries under consideration experienced a build-up of large external imbalances. In fact, in the period 2004 - 2007, Czechia and Slovenia were the only countries with CA deficits below the threshold of $-4 \%$ (as later established within the EU's Macroeconomic Imbalance Procedure). The CA deficits were particularly large in the Baltics, where they were found to originate from capital inflow-driven domestic booms (Kang and Shambaugh, 2013). The outbreak of the crisis brought to light those imbalances, and many of the EU members of Central and Eastern Europe saw a temporary withdrawal of foreign capital. Some of them, including Latvia and Hungary, were forced to seek balance of payments assistance from international creditors. ${ }^{9}$ In the wake of the crisis, substantial current account adjustments were observed. Nonetheless, at least initially, the reductions in trade deficits were achieved by a sharp decline in imports, spurred by a strong contraction of domestic demand (ECB, 2014). It is in this context that we explain the negative sign of the parameter estimate for the $C A$ variable.

Analyzing the impact of other macroeconomic variables, we find the link between the ratings and unemployment rates in the ,new“ EU members in each of the distinguished sub-periods. As expected, the corresponding coefficient is negative, which means that the rise in unemployment had a negative impact on the credit ratings of the analysed countries. The results of our study can be supported by the statement that an increase in the unemployment rate poses a serious risk of insolvency in the EU countries (Chodnicka-Jaworska, 2015).

Finally, we observe that the fundamental-based variable Private debt had a statistically significant impact on the credit ratings in the first sub-period (before the crisis), as well as in the third sub-period (i.e. after the crisis). The Private debt parameter estimate is negative, which is in line with expectations. In the period $2004 q 1-2008 q 2$, private debt in the analysed countries grew successively, which was most likely due to the increasing availability of loans for households

\footnotetext{
${ }^{9}<$ https://ec.europa.eu/info/business-economy-euro/economic-and-fiscal-policy-coordination/ financial-assistance-eu/funding-mechanisms-and-facilities/balance-payments-bop-assistancefacility_en\#overview-of-balance-of-payments-assistance-programmes>; Accessed December 5, 2020.
} 
and enterprises. In turn, during the crisis, there were liquidity shortages in the banking sector. Popescu and Turcu (2014) note that shortages of bank liquidity reduce credit to the private sector, leading to a decline in consumption and private investment, and hence in production, which then results in fiscal imbalances. In addition, it should be emphasised that domestic banking and financial sectors have different structures, sizes and degrees of exposure to global financial conditions, and an increase in the common aggregate risk factor may cause heterogeneous effects on national public debt servicing costs. Private debt in the third sub-period, i.e. 2013q1 - 2018q4, was influenced by many changes in the banking sector introduced after the financial crisis, which resulted in a more cautious approach to lending to the economy. Miele and Sales (2011) point to several regulations in the banking system after the global financial crisis that aimed to promote a more resilient banking system and improve its ability to absorb financial and economic shocks. In particular, they highlighted the role of the Financial Stability Board and the Basel Committee in developing a comprehensive plan to strengthen banking regulations and macroprudential policy.

Turning to the $E M U$ variable, it is statistically significant in each of the three sub-periods, and the signs of the parameter estimates are positive. It seems that the euro area countries derived additional benefits in terms of perceived credibility from merely being EMU members. In the pre-crisis period, it might have been because the euro area was seen as an ,elite club" of developed European economies. The monetary policy was transferred to the level of the ECB, which was supposed to build upon the Bundesbank's impeccable record of preserving price stability, and the rest of the euro area countries experienced economic benefits (like lower interest rates) through the deepening of integration with Germany. That way, and amid the Great Moderation period, the risks associated with investing in the euro area, including the analysed countries, could have been under-priced (cf. Bernoth and Erdogan, 2012; Oliveira, Curto and Nunes, 2012). The outbreak of the 2008 financial crisis, which later evolved into a sovereign debt crisis of the euro area, revealed many institutional deficiencies of the EMU and put the common currency project into question.

Despite all the tensions related to the crisis, the impact of the $E M U$ variable on the ratings is positive. This finding contrasts with the results of Reusens and Croux (2017) and Stawasz-Grabowska (2020), who identified a switch from a positive to a negative effect of euro area membership during the crisis period. Nonetheless, those studies took into account all EU countries, including those euro area members which were most adversely affected during the crisis. That is not the case in this study. Interestingly, the variable remains significant in the third sub-period. It might indicate that the European policymakers had successfully 
addressed some of the main flaws in the construction of the EMU. In particular, the lender of last resort for sovereigns and a central supervisory authority had been established, the absence of which was severely criticised from the very beginning of the euro area project (cf. Bordo and Jonung, 1999; Prati and Schinasi, 2000).

Assessing the impact of the qualitative variables, the coefficient estimate for Governance proved to be significant throughout 2004 - 2018, and it was particularly large in the second and third sub-periods. Thus, the quality of regulation, sound policies, and respect for institutions that manage economic interactions play an important role in sovereign risk assessment. This idea is highlighted by Mellios and Paget-Blanc (2006), Butler and Fauver (2006) and Alexe et al. (2003), who found the quality of legal and political institutions to be important determinants in rating models. Our findings are also in line with the conclusions obtained by Boysen-Hogrefe (2017), who uses the composite World Bank indicator on the quality of governance as a proxy for countries' willingness and capability to cooperate in favour of economic and fiscal policy in the EMU. The author points to a diminished role of macroeconomic fundamentals in the postOMT period to the advantage of governance quality. Our study provides similar conclusions for the „new“ EU member states, including those which retain control over their monetary policy.

\section{Conclusions}

In this paper, we have studied the determinants of the sovereign credit ratings of nine countries that joined the ranks of the EU in 2004. The comprehensive literature on country default risk has admittedly included these economies, but they rarely constituted the focal point and were treated more as part of a larger group of countries (like European emerging markets). The analysis was conducted for the period from 2004q1 to 2018q4, which was later divided into pre-crisis, crisis, and post-crisis sub-periods. This has allowed us to examine whether the impact of the identified factors on ratings was stable regardless of volatile and changing economic conditions. Additionally, the division of countries into euroarea and non-euro area member states has allowed us to contribute to the existing literature on bias in sovereign credit ratings.

Our main findings can be summarised as follows. First, the sovereign credit ratings of the analysed countries have proved to be strongly influenced by macroeconomic factors from the realm of fiscal and monetary policy (policy mix), especially during the crisis. More specifically, government debt and unemployment played an important role throughout the period under review. Then, GDP growth was significant before and during the crisis; private debt had a significant 
impact on credit ratings before and after the crisis; finally, inflation and CA were important during the crisis. Second, our study demonstrates that the euro area countries derived additional benefits in terms of perceived credibility from simply being EMU members. Third, our results indicate that the ratings of the „new“ EU members are strongly influenced by the quality of governance, which has not proved to be a time-dependent factor.

When it comes to policy implications, our study might be of particular interest for non-euro area EU member states. We draw attention to the additional benefit experienced by less developed EU countries from simply being a member of the EMU. And even though many institutional issues in the euro area remain unaddressed (like the common euro area budget as a potential shock absorber and common safe asset), it seems that ,new“ EU countries are not necessarily better off staying on the sidelines of the European integration process. Secondly, our study shows the relative importance of governance (against macroeconomic factors) as a determinant of country default risk in the post-crisis years, not only for the „old“ EU countries, as previously found, but for the „new“ member states as well. It should be particularly important for countries such as Hungary and Poland, whose governance assessments have been recently lowered.

\section{References}

AFONSO, A. (2003): Understanding the Determinants of Sovereign Debt Ratings: Evidence for the Two Leading Agencies. Journal of Economics and Finance, 27, No. 1, pp. 56 - 74. DOI: $10.1007 / \mathrm{bf02751590.}$

AFONSO, A. - ARGHYROU, M. - GADEA, M. - KONTONIKAS, A. (2018): „Whatever It Takes" to Resolve the European Sovereign Debt Crisis? Bond Pricing Regime Switches and Monetary Policy Effects. Journal of International Money and Finance, 86, No. C, pp. 1 - 30. DOI: 10.1016/j.jimonfin.2018.04.005.

AFONSO, A. - GOMES, P. - ROTHER, P. (2011): Short- and Long-run Determinants of Sovereign Debt Credit Ratings. International Journal of Finance - Economics, 16, No. 1, pp. 1 - 15. DOI: $10.1002 / \mathrm{ijfe} .416$.

ALEXE, S. - HAMMER, P. - KOGAN, A. - LEJEUNE, M. (2003): A Nonrecursive Regression Model for Country Risk Rating. [Rutcor Research Report 9-2003.] New York: Rutgers Center for Operational Research.

ALEXY, M. - KÁČER, M. - OCHOTNICKÝ, P. (2014): Visegrad Four Countries and their Sovereign Credit Rating. Ekonomický časopis/Journal of Economics, 62, No. 5, pp. 447 - 472. DOI: $10.2139 / \mathrm{ssrn} .2584978$.

BEIRNE, J. - FRATZSCHER, M. (2013): The Pricing of Sovereign Risk and Contagion during the European Sovereign Debt Crisis. Journal of International Money and Finance, 34, No. C, pp. 60 - 82. DOI: 10.1016/j.jimonfin.2012.11.004.

BERNOTH, K. - ERDOGAN, B. (2012): Sovereign Bond Yield Spreads: A Time-varying Coefficient Approach. Journal of International Money and Finance, 31, No. 3, pp. 639 - 656. DOI: $10.1016 /$ j.jimonfin.2011.10.006.

BISSOONDOYAL-BHEENICK, E. (2005): An Analysis of the Determinants of Sovereign Ratings. Global Finance Journal, 15, No. 3, pp. 251 - 280. DOI: 10.1016/j.gfj.2004.03.004. 
BORDO, M. - JONUNG, L. (1999): The Future of EMU: What Does the History of Monetary Unions Tell Us? [Working Paper 7365.] Cambridge: National Bureau of Economic Research, pp. 1 - 40. Available at: <https://www.nber.org/papers/w7365>.

BOUMPARIS, P. - MILAS, C. - PANAGIOTIDIS, T. (2017): Economic Policy Uncertainty and Sovereign Credit Rating Decisions: Panel Quantile Evidence for the Eurozone. Journal of International Money and Finance, 79, No. C, pp. 39 - 71. DOI: 10.1016/j.jimonfin.2017.08.007.

BOUMPARIS, P. - MILAS, C. - PANAGIOTIDIS, T. (2019): Non-performing Loans and Sovereign Credit Ratings. International Review of Financial Analysis, 64, July, p. $301-314$. DOI: $10.1016 /$ j.irfa.2019.06.002.

BOYSEN-HOGREFE, J. (2017): Risk Assessment on Euro Area Government Bond Markets - The Role of Governance. Journal of International Money and Finance, 73, No. PA, pp. $104-117$. DOI: 10.1016/j.jimonfin.2017.01.005.

BUTLER, A. - FAUVER, L. (2006): Institutional Environment and Sovereign Credit Ratings. Financial Management, 35, No. 3, pp. 53 - 79. DOI: 10.1111/j.1755-053x.2006.tb00147.x.

CANTOR, R. - PACKER, F. (1996): Determinants and Impact of Sovereign Credit Ratings. SSRN Electronic Journal. DOI: 10.2139/ssrn.1028774.

CHAREMZA, W. - DEADMAN, D. (2003): New Directions in Econometric Practice. Cheltenham: Elgar.

CHARI, A. - GARCÉS, F. - MARTÍNEZ, J. - VALENZUELA, P. (2019): Sovereign Credit Risk, Financial Fragility, and Global Factors. Available at: <http://www.up.edu.pe/UP_Landing/ conference-financial-stability-sustainability/documents/Valenzuela-Paper.pdf>.

CONNOLLY, M. (2007): Measuring the Effect of Corruption on Sovereign Bond Ratings. Journal of Economic Policy Reform, 10, No. 4, pp. 309 - 323. DOI: 10.1080/17487870701552053.

De GRAUWE, P. - JI, Y. (2014): The Future of the Eurozone. The Manchester School, 82, No. S1, pp. 15 - 34. DOI: 10.1111/manc. 12077.

De MOOR, L. - LUITEL, P. - SERCU, P. - VANPÉE, R. (2018): Subjectivity in Sovereign Credit Ratings. Journal of Banking - Finance, 88, No. C, pp. 366 - 392. DOI: 10.1016/j.jbankfin.2017.12.014.

DIMITRAKOPOULOS, S. - KOLOSSIATIS, M. (2015): State Dependence and Stickiness of Sovereign Credit Ratings: Evidence from a Panel of Countries. Journal of Applied Econometrics, 31, No. 6, pp. 1065 - 1082. DOI: 10.1002/jae.2479.

DOPIERAŁA, Ł. - ILCZUK, D. - WOJCIECHOWSKI, L. (2020): Sovereign Credit Ratings and CDS Spreads in Emerging Europe. Equilibrium, 15, No. 3, pp. 419 - 438. DOI: $10.24136 /$ eq.2020.019.

ECB (2014): Monthly Bulletin March 2014. Frankfurt am Main: ECB.

EHRMANN, M. - FRATZSCHER, M. (2017): Euro Area Government Bonds - Fragmentation and Contagion during the Sovereign Debt Crisis. Journal of International Money and Finance, 70, No. C, pp. 26 - 44. DOI: 10.1016/j.jimonfin.2016.08.005.

EICHLER, S. (2014): The Political Determinants of Sovereign Bond Yield Spreads. Journal of International Money and Finance, 46, No. C, pp. 82 - 103. DOI: 10.1016/j.jimonfin.2014.04.003.

ERDEM, O. - VARLI, Y. (2014): Understanding the Sovereign Credit Ratings of Emerging Markets. Emerging Markets Review, 20, No. C, pp. 42 - 57. DOI: 10.1016/j.ememar.2014.05.004.

GIORDANO, R. - PERICOLI, M. - TOMMASINO, P. (2013): Pure or Wake-up-Call Contagion? Another Look at the EMU Sovereign Debt Crisis. International Finance, 16, No. 2, pp. $131-160$. DOI: $10.1111 / \mathrm{j} .1468-2362.2013 .12033 . x$.

GRABOWSKI, W. - STAWASZ, E. (2017): Sovereign Bond Spreads in the EMU Peripheral Countries. The Role of the Outright Monetary Transactions. Prague Economic Papers, 26, No. 3, pp. 360 - 373. DOI: 10.18267/j.pep.618.

HAJRIA, R. - KHARDANI, S. - RAÏSSI, H. (2018): A Power Comparison between Autocorrelation Based Tests. Statistics - Probability Letters, 143, No. C, pp. 1 - 6. DOI: 10.1016/j.spl.2018.07.015. 
KANG, J. - SHAMBAugH, J. (2013): The Evolution of Current Account Deficits in the Euro Area Periphery and the Baltics: Many Paths to the Same Endpoint. [International Monetary Fund WP/13/169.] Washington, DC: IMF.

KILPONEN, J. - LAAKKONEN, H. - VILMUNEN, J. (2015): Sovereign Risk, European Crisis Resolution Policies and Bond Yields. International Journal of Central Banking, 11, No. 2, pp. 285 - 323. DOI: 10.2139/ssrn.2102461.

LUITEL, P. - VANPÉE, R. - De MOOR, L. (2016): Pernicious Effects: How the Credit Rating Agencies Disadvantage Emerging Markets. Research in International Business and Finance, 38, No. C, pp. 286 - 298. DOI: 10.1016/j.ribaf.2016.04.009.

MELLIOS, C. - PAGET-BLANC, E. (2006): Which Factors Determine Sovereign Credit Ratings? The European Journal of Finance, 12, No. 4, pp. $361-377$. DOI: $10.1080 / 13518470500377406$.

MIELE, M. - SALES, E. (2011): The Financial Crisis and Regulation Reform. Journal of Banking Regulation, 12, No. 4, pp. 277 - 307. DOI: 10.1057/jbr.2011.7.

MIRICESCU, E. - ȚÂŢU, L. - CORNEA, D. (2016): The Determinants of the Sovereign Debt Rating: Evidence for the European Union Countries. Economic Computation and Economic Cybernetics Studies and Research, 50, No. 1, pp. 175 - 188.

MONFORT, B. - MULDER, C. (2000): Using Credit Ratings for Capital Requirements on Lending to Emerging Market Economies - Possible Impact of a New Basel Accord. [IMF Working Papers 2000/069.] Washington, DC: International Monetary Fund.

OLIVEIRA, L. - CURTO, J. - NUNES, J. (2012): The Determinants of Sovereign Credit Spread Changes in the Euro-zone. Journal of International Financial Markets, Institutions and Money, 22, No. 2, pp. 278 - 304. DOI: 10.1016/j.intfin.2011.09.007.

POPESCU, A. - TURCU, C. (2014): Systemic Sovereign Risk in Europe: An MES and CES Approach. Revue D'économie Politique, 124, No. 6, pp. 899 - 925. DOI: 10.3917/redp.246.0899.

PRATI, A. - SCHINASI, G. (2000): Will the European Central Bank Be the Lender of Last Resort in EMU. In: ARTIS, M., WEBER, A. and HENNESSY, E. The Euro: A Challenge and Opportunity for Financial Markets. London/New York: Routledge.

REUSENS, P. - CROUX, C. (2017): Sovereign Credit Rating Determinants: A Comparison before and after the European Debt Crisis. Journal of Banking - Finance, 77, No. C, pp. $108-121$. DOI: 10.1016/j.jbankfin.2017.01.006.

SEHGAL, S. - MATHUR, S. - ARORA, M. - GUPTA, L. (2018): Sovereign Ratings: Determinants and Policy Implications for India. IIMB Management Review, 30, No. 2, pp. 140 - 159. DOI: 10.1016/j.iimb.2018.01.006.

STAWASZ-GRABOWSKA, E. (2020): Sovereign Credit Rating Determinants of the EU Countries: The Role of the Euro Area Crisis and Its Legacy. Entrepreneurial Business And Economics Review, 8, No. 2, pp. 47 - 69. DOI: 10.15678/eber.2020.080203.

STUBELJ, I. - DOLENC, P. (2010): Fiscal Sustainability of EU Member States in the Context of Current Financial Crisis, Economic Research-Ekonomska Istraživanja, 23, No. 4, pp. 37 - 62. DOI: 10.1080/1331677X.2010.11517432.

TEIXEIRA, J. - SILVA, F. - FERREIRA, M. - VIEIRA, J. (2018): Sovereign Credit Rating Determinants under Financial Crises. Global Finance Journal, 36, No. C, pp. 1 - 13. DOI: $10.1016 /$ j.gfj.2018.01.003.

TENNANT, D. - TRACEY, M. - KING, D. (2018): Sovereign Credit Rating: Evidence of Bias Against Poor Countries. The North American Journal of Economics and Finance, 51, January 2020, No. 100877, pp. 1 - 13. Available at: <https://www.sciencedirect.com/science/article/abs/pii/S1062940818302158>.

WILSON, N. - OCHOTNICKY, P. - KACER, M. (2014): Sovereign Credit Ratings and the New European Union Member States. Journal of Credit Risk, 10, No. 4, pp. 3 - 43.

WINKLER, A. (2015): The ECB as Lender of Last Resort: Banks versus Governments. Jahrbücher Für Nationalökonomie Und Statistik, 235, No. 3, pp. 329 - 341. DOI: 10.1515/jbnst-2015-0307. 